\title{
A SURVEY OF CONGENITAL CHAGAS' DISEASE, CARRIED OUT AT THREE HEALTH INSTITUTIONS IN SÃO PAULO CITY, BRAZIL
}

Isabelle Vera Vichr NISIDA(1), Vicente AMATO NETO(2), Lúcia Maria Almeida BRAZ(2), Maria Irma Seixas DUARTE(3) \& Eufrosina Setsu UMEZAWA(4)

\begin{abstract}
SUMMARY
The congenital transmission of Chagas' disease was evaluated in 57 pregnant women with Chagas' disease and their 58 offspring. The patients were selected from three Health Institutions in São Paulo City. The maternal clinical forms of Chagas' disease were: indeterminate (47.4\%), cardiac (43.8\%) and digestive (8.8\%); 55 were born in endemic areas and two in São Paulo City. The transmission of Chagas' disease at fetal level was confirmed in three $(5.17 \%)$ of the 58 cases studied and one probably case of congenital Chagas' disease. Two infected infants were born to chagasic women with HIV infection and were diagnosed by parasitolological assays (microhematocrit, quantitative buffy coat-QBC or artificial xenodiagnosis). In both cases the placenta revealed T. cruzi and HIV p24 antigens detected by immunohistochemistry. In one case, a 14-week old abortus, the diagnosis of congenital $T$. cruzi infection was confirmed by immunohistochemistry. The other probable infection, a 30-week old stillborn, the parasites were found in the placenta and umbilical cord.

The Western blot method using trypomastigote excreted/secreted antigens of T. cruzi (TESA) was positive for IgG antibodies in $54 / 55$ newborns and for IgM in $1 / 55$ newborns. One of the two newborns with circulating parasites had no detectable $\operatorname{IgG}$ or IgM antibodies.

The assessment of IgG antibodies in the sera of pregnant women and their newborns was performed by ELISA using two different T. cruzi antigens: an alkaline extract of epimastigotes (EAE) and trypomastigote excreted/secreted antigens (TESA). The analysis showed a linear correlation between maternal and newborn IgG antibody titers at birth.
\end{abstract}

KEYWORDS: Trypanosoma cruzi; Chagas' disease; Congenital Chagas' disease; Chagas' disease and HIV; Immunohistochemistry for parasites; TESA.

\section{INTRODUCTION}

The congenital transmission of Trypanosoma cruzi has been described by several authors ${ }^{3,7,12}$. Its frequency varies according to the area studied and methodology employed. In 1960, LISBOA ${ }^{18}$ described for the first time the presence of amastigote forms of T. cruzi in a stillborn and its placenta, confirming infection through the transplacental route. In studies conducted in the sixties and seventies, anatomopathological examination of material collected from abortions and stillborn fetuses showed that death occurred because of chagasic infection ${ }^{4,5,7}$. Since 1980 , prospective work has shown that different clinical forms of congenital Chagas' disease can be identified with the aid of different methods of diagnosis such as parasitological and serological tests and anatomopathological studies ${ }^{7,22,23}$. Congenital Chagas' disease is manifested in several ways: intra-uterine death during any fetal phase, prematurity, hepatosplenomegaly, fever and/or cardiac problems, nervous and digestive manifestations. The newborns may be at birth asymptomatic ${ }^{5,12}$. There are regional differences in the incidence rates of congenital chagasic infection, which vary from $1.1 \%$ to $18.5 \%$ when parasitological methods are applied for diagnosis $2,3,6,22,24,26$. The risk factors for recurrent congenital transmission by chagasic pregnant women have not been clearly defined, but may be influenced by the strains of $T$. cruzi or the level of parasitemia ${ }^{8}$. The presence of $T$. cruzi at birth substantiates the diagnosis of congenital Chagas' disease. The detection of IgM antibodies by serological methods is possible with the use of a specific acute phase protein (SAPA) in Western blotting ${ }^{32}$, or SAPA recombinant proteins ${ }^{19}$, but these antibodies are not always found at birth in spite of the presence of circulating $T$. cruzi $i^{3,6,12,19}$

The main objective of this study was to investigate the incidence of congenital Chagas' disease in three institutions specialized in the care of high risk pregnant women in São Paulo City, Brazil.

\section{MATERIAL AND METHODS}

\section{Patients}

Fifty seven pregnant women and their 58 newborns were chosen from three high risk obstetric clinics in São Paulo City: 25 patients from

(1) Post-graduate student, Departamento de Doenças-Infecciosas e Parasitárias da Faculdade de Medicina da USP, São Paulo, SP, Brasil

(2) Laboratório de Parasitologia do Instituto de Medicina Tropical de São Paulo-USP, São Paulo, SP, Brasil

(3) Departamento de Patologia da Faculdade de Medicina da USP, São Paulo, SP, Brasil

(4) Laboratório de Protozoologia do Instituto de Medicina Tropical de São Paulo-USP, São Paulo, SP, Brasil

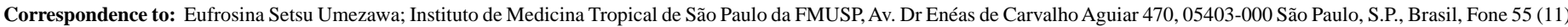
3066 7017. E-mail: eumezawa@usp.br 


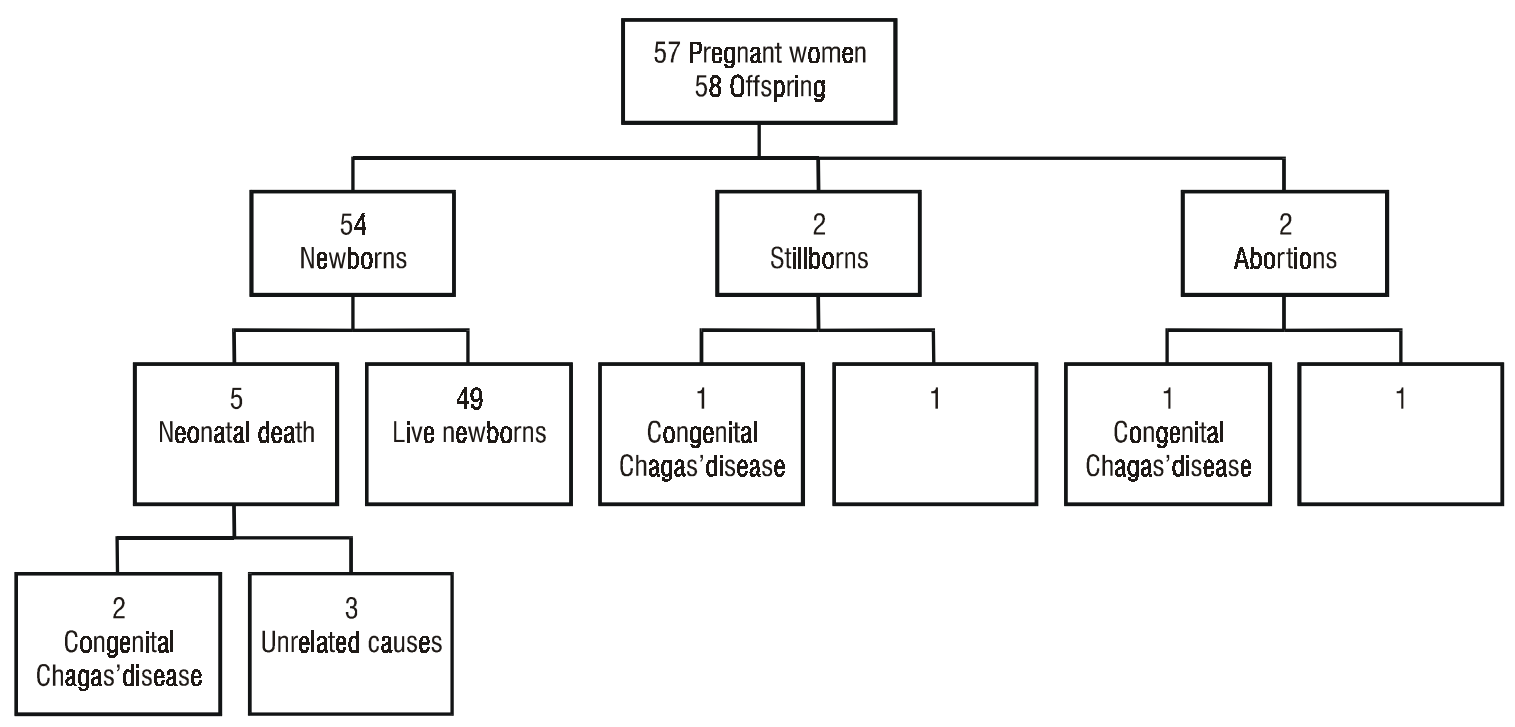

Fig. 1 - Pregnancy outcome of 57 chagasic women in the chronic phase, and identification of congenital transmission of Trypanosoma cruzi

the University Hospital, Faculty of Medicine, Discipline of Obstetrics; 19 from the Maternity Hospital Leonor Mendes de Barros, and 13 from the Dante Pazzanese Institute of Cardiology (Cardiologic and Obstetric Sectors). Forty-two pregnant women had a previous diagnosis of Chagas' disease and 15 had been diagnosed during prenatal examination. Serological tests were negative for syphilis but two were positive for HIV (2/36). Fifty-five patients were from endemic areas for Chagas' disease, and two where born in São Paulo City (the daughter of a chagasic woman and a woman submitted to blood transfusion). Fifty-seven pregnant women were classified in indeterminate $(47.4 \%, n=27)$, digestive $(8.8 \%, n=5)$ and cardiac forms $(43.8 \%, n=25)$ (according to clinical and laboratory evaluation, and electrocardiogram data). Childbirth occurred by vaginal delivery in $49.1 \%(n=28)$, and by cesarean section in $47.4 \%(n=27)$; spontaneous abortion occurred in $3.5 \%(n=2)$. The average age of the pregnant women was 32 years (21 to 44). The newborn data recorded at birth were: classification of age (Capurro), weight, $1^{\text {st }}$ and $5^{\text {th }}$ minute APGAR scores and data of physical examination. Infants born to these infected women were submitted to clinical, parasitological and serological examinations at birth. The anatomopathological examination was done in material collected from abortions and stillborns.

\section{Parasitological tests}

Parasitemia was determined in the 54 newborns. The parasitological tests were microhematocrit ${ }^{25}$, quantitative buffy coat (QBC) ${ }^{1}$ and artificial xenodiagnosis. The microhematocrit and QBC were also determined for the 46 pregnant women. Artificial xenodiagnosis was performed using 1 to $3 \mathrm{ml}$ of venous blood and sometimes with cord blood collected with anticoagulant (heparin or EDTA). The collected blood was placed in a container covered with transparent PVC film (Magipack ${ }^{\circledR}$ ), heated to $37^{\circ} \mathrm{C}$, and offered as a meal to $203^{\text {rd }}$ and $4^{\text {th }}$ instar nymphs of Triatoma infestans for 45 minutes. The presence of T. cruzi was determined in the vector's feces 30 and 60 days after the blood meal.

\section{Serological tests}

Enzyme-linked-immunosorbent-assay (ELISA) was performed using 2 different antigens from $T$. cruzi: i) trypomastigote excreted/secreted antigens (TESA) ${ }^{32}$, and ii) epimastigote alkaline extract (EAE) ${ }^{32,33}$. The ELISAs were processed as described ${ }^{33}$. The results were expressed as OD $492 \mathrm{~nm}\left(\mathrm{OD}_{492}\right)$. Samples from the pregnant women and their offspring were recorded as positive or negative in relation to the cutoff value. The confirmatory diagnosis of Chagas' disease was performed by Western blot using TESA as antigens (TESA-blot), processed as previously described ${ }^{32}$. The results of the search for IgG and IgM anti-T. cruzi antibodies were defined as positive by the naked-eye observation of bands.

\section{Histological and immunohistochemistry methods}

Histological analysis was performed in 12 placentas, in two autopsies of stillborns and in two umbilical cord. Formaldehyde-fixed paraffinembedded sections were stained with hematoxylin-eosin (HE) and also examined for detection of $T$. cruzi antigen by immunohistochemistry $(\mathrm{IH})^{11,28}$. Immunohistochemical analysis for HIV p24 antigen (M 857/ DAKO) was also performed in sections of placentas of two newborns, and one autopsy case of a dead newborn all from HIV-positive mothers.

\section{RESULTS}

The 58 offspring born to 57 chagasic pregnant women were represented by 54 newborns, with five neonatal deaths, two stillborns and two abortions (Fig. 1).

The average weight of the 54 newborns was $3140 \mathrm{~g}$. Weight adjusted for gestational age was appropriate in $83.3 \%$ of cases $(n=45)$ but $13 \%$ $(n=7)$ were small-for-gestational-age and only $3.7 \%(n=2)$ were largefor-gestational-age; $90.7 \%(n=49)$ of the deliveries were at term, $7.4 \%$ $(n=4)$ pre-term and $1.9 \%(n=1)$ post-term. Low APGAR score at the first minute was observed in $11.3 \%(6 / 53)$ of the newborns, but two newborns recovered vitality by the $5^{\text {th }}$ minute.

Among the 54 newborns, 49 were discharged from the hospital without abnormalities; 13 had physiological jaundice and five presented anomalies (one CIV and four minor anomalies). Five died within the 
perinatal period: two from Chagas' disease and three from unrelated causes (Fig 1).

The parasitological methods applied to the 54 newborns were positive in two cases (case 1 and case 2 in Table 1) and in pregnant women was positive in 1/46 for QBC (Table 2).
Two newborns congenitally infected were born from women coinfected with HIV (Tables 1 and 2). These mothers showed anti-T. cruzi IgM antibodies by TESA-blot and two were positive by xenodiagnosis and one by QBC. They also presented respectively 185 and 406 CD4/ $\mathrm{mm} 3$. The mother of case 1 had received antiretroviral therapy (zidovudine, $200 \mathrm{mg} / \mathrm{tid}$ ), from the second trimester of pregnancy to the

Table 1

Summary of clinical, parasitological, serological and anatomopathological data of four children with congenital Chagas' disease

\begin{tabular}{|c|c|c|c|c|c|}
\hline \multirow[b]{3}{*}{ Concept age } & \multirow[b]{3}{*}{ Week \# } & \multicolumn{4}{|c|}{ Case } \\
\hline & & $1^{*}$ & $2 *$ & $3^{\Delta}$ & 4 \\
\hline & & 40 & 33 & 30 & 14 \\
\hline Physical Examination & & $\begin{array}{c}\text { Respiratory } \\
\text { distress } \\
\text { syndrome, } \\
\text { seizure, anemia }\end{array}$ & $\begin{array}{l}\text { Hepatosplenomegaly, } \\
\text { meningoencephalitis, } \\
\text { myocarditis, femur } \\
\text { metaphysitis, anemia }\end{array}$ & Macerated fetus & Macerated fetus \\
\hline Weight (g) & & 3640 & 1125 & 555 & 90 \\
\hline Survival & & 10 hours & 30 days & & \\
\hline Parasitological tests & $\mathrm{QBC} / \mathrm{mht} / \mathrm{xeno}$ & + & + & nd & nd \\
\hline \multirow[t]{3}{*}{ Serological tests for T.cruzi } & ELISA IgG & + & - & + & nd \\
\hline & WB IgG & + & - & + & nd \\
\hline & WB IgM & + & - & - & nd \\
\hline \multirow[t]{5}{*}{$\begin{array}{l}\text { Anatomopathological } \\
\text { examination for T.cruzi }\end{array}$} & Placenta HE & Ama - & $\begin{array}{c}\text { Ama }+ \\
\text { Chronic villitis }\end{array}$ & $\begin{array}{c}\text { Ama - } \\
\text { Plasmocitary villitis }\end{array}$ & nd \\
\hline & Placenta IH & $\mathrm{Ag}+$ & Ama + & $\begin{array}{l}\text { Decidua+, villus+, } \\
\text { Hofbauer cells+ }\end{array}$ & nd \\
\hline & Umbilical cord $\mathrm{HE}$ & Ama - & nd & Ama - & nd \\
\hline & Umbilical cord IH & $\mathrm{Ag}+$ & nd & $\mathrm{Ag}+$ & nd \\
\hline & Fetal organs IH & nd & $\begin{array}{l}\mathrm{Ag}+ \\
\text { heart and liver }\end{array}$ & nd & $\begin{array}{c}\mathrm{Ag}+ \\
\text { CNS autolysis }\end{array}$ \\
\hline $\begin{array}{l}\text { Anatomopathological } \\
\text { results for p24-HIV }\end{array}$ & Placenta IH & $\begin{array}{c}\text { Ag + } \\
\text { villus and } \\
\text { membranes }\end{array}$ & $\begin{array}{c}\text { Ag + } \\
\text { villus and } \\
\text { membranes }\end{array}$ & nd & nd \\
\hline
\end{tabular}

\# calculated by Capurro;

*from pregnant women with HIV and T. cruzi co-infection;

$\Delta$ possible congenital Chagas' disease;

+ positive;

- negative;

QBC: quantitative buffy coat;

Mht: microhematocrit;
Xeno: artificial xenodiagnosis;

nd: not done;

HE: hematoxilina-eosina;

IH: immunohistochemistry;

Ama: amastigote form of T.cruzi;

CNS: central nervous system;

Ag: antigen 
$30^{\text {th }}$ week of gestation when the HIV viral load was 35,600 copies $/ \mathrm{ml}$. Other details are summarized in Table 2.

Case 1 newborn died, during the neonatal period, with 10 hours of life, and autopsy was not performed. The infant had a third trimester placenta showing no inflammatory response or amastigotes forms by HE. T. cruzi antigen was detected in the decidua, villus stroma, cytotrophoblast, membranes and umbilical cord. The congenital transmission of HIV could not be proved in this case despite the presence of the p24 HIV antigen in the placenta membrane. The principal aspects of anatomopathological examination and others details are summarized in Table 1.

Case 2 newborn died 30 days after birth despite the introduction of benznidazole treatment $(20 \mathrm{mg} / \mathrm{kg} / \mathrm{day})$. The autopsy findings showed bilateral pulmonary infarction, hepatosplenomegaly, digestive bleeding, and jaundice. Histology of the heart showed multifocal interstitial lymphocytic infiltration and necrosis of myocardial fibers. In the liver diffuse hypertrophy of Kupffer cells, intralobular cholesthasis and hepatocytic steatosis and inflammatory infiltration in portal spaces were observed. Intact $T$. cruzi amastigote forms were not detected by IH but T. cruzi antigen was present in myocardial fibers and Kupffer cells. Histology showed a third trimester placenta with chronic villitis, endarteritis, amastigotes forms in villus stroma and Hofbauer cell. T. cruzi antigen delineate amastigotes forms and antigen particles were present in villus stroma and Hofbauer cell. HIV p24 antigen was positive by $\mathrm{IH}$ in the villus and membrane of placenta, but the congenital transmission of HIV could not be proved also in this case.
Anatomopathological study was not performed in the stillborn (case 3 ), whose placenta presented intact $T$. cruzi amastigotes in the decidua, syncytiotrophoblast, Hofbauer cells and in the stroma, and T. cruzi antigen was found in the Wharton jelly of umbilical cord (Table 1).

In case 4, a 14 week-old macerated fetus, in spite of autolysis, $T$. cruzi antigens were detected by $\mathrm{IH}$ in the central nervous system.

The HE/IH examinations were not done in one abortus and in one 38 week-old stillborn twin (Figure 1). The other twin, a newborn showed no evidence of placental infection. The other nine placentas do not showed amastigote forms and T. cruzi antigen by the histological and IH studies.

Specific anti-T. cruzi IgG antibodies were found in 54/55 newborns by ELISA and TESA-blot. The IgM antibodies were detected only in case $1(1 / 55)$ by TESA-blot (Table 1$)$. Despite high parasitemia, case 2 presented no anti-T. cruzi IgG or IgM detectable in the serum. The surviving twin presented decreasing anti-T. cruzi IgG titers during followup, until he reached negative results after 6 months, demonstrating absence of congenital infection.

The concordance in anti-T. cruzi IgG levels in mother and newborn sera was almost perfect in the pairs tested. Only one newborn presented negative results, but the usual maternal antibody levels were present in infants serum. Serological patterns of specific anti-T. cruzi antibodies were tested by correlation between EAE and TESA, by ELISA (Fig.2). TESA-specific antibodies presented a higher correlation between maternal and newborn IgG antibodies, with $\mathrm{r}^{2}=0.386(\mathrm{p}<0.0001)$,

Table 2

Summary of congenital cases-maternal data

\begin{tabular}{|c|c|c|c|c|c|}
\hline \multirow[b]{3}{*}{ Age } & \multirow[b]{3}{*}{ years } & \multicolumn{4}{|c|}{ Case } \\
\hline & & $1 *$ & $2 *$ & 3 & 4 \\
\hline & & 30 & 28 & 40 & 30 \\
\hline Clinical form & & Indeterminate & Indeterminate & Indeterminate & Indeterminate \\
\hline Procedence (Brazil) & & Bahia & Bahia & Minas Gerais & Bahia \\
\hline Weeks of pregnancy & & 41 & 29 & 30 & 14 \\
\hline \multirow[t]{2}{*}{ Parasitology } & QBC & - & + & - & - \\
\hline & Xeno & + & + & nd & nd \\
\hline \multirow[t]{2}{*}{ TESA-blot } & $\operatorname{IgG}$ & + & + & + & + \\
\hline & $\operatorname{IgM}$ & + & + & - & - \\
\hline CD4 number cell & $\mathrm{mm}^{3}$ & 185 & 406 & nd & nd \\
\hline Viral load copy & $\mathrm{ml}$ & 35600 & nd & nd & nd \\
\hline
\end{tabular}

* cases with HIV; - negative; + positive; nd not done; QBC quantitative buffy coat; Xeno artificial xenodiagnosis 
compared with the low level correlation of $\mathrm{r}^{2}=0.178(\mathrm{p}=0.0067)$ found with EAE. These data suggest that most all of the maternal antibodies could be transferred by the placenta to the newborn, since only one case showed IgM anti-T.cruzi production, specific for a newborn response.

\section{DISCUSSION}

Congenital transmission of Chagas' disease occurred in $5.17 \%$ of our patients series $(3 / 58)$, plus one probable case. The parasitological method detected T. cruzi in two of 54 newborns, and the other cases were diagnosed by histological and immunohistochemistry methods.

The transplacentary transmission of $T$. cruzi has been shown in several stages of pregnancy ${ }^{5,8,12}$, with risk of $T$. cruzi transmission during the successive pregnancies ${ }^{5,8}$ of chagasic mothers.

Parasitological methods in general are the diagnostic tests of choice in acute congenital Chagas' disease ${ }^{6,7,12}$, but xenodiagnosis is not easily performed due to the need for laboratory triatomines and to the long time needed to obtain the results ${ }^{7}$. The microhematocrit and QBC methods

A

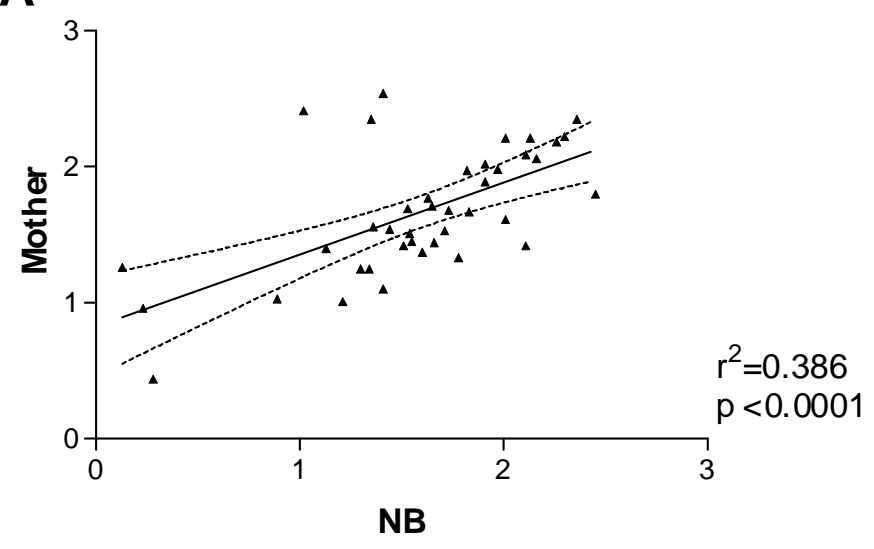

B

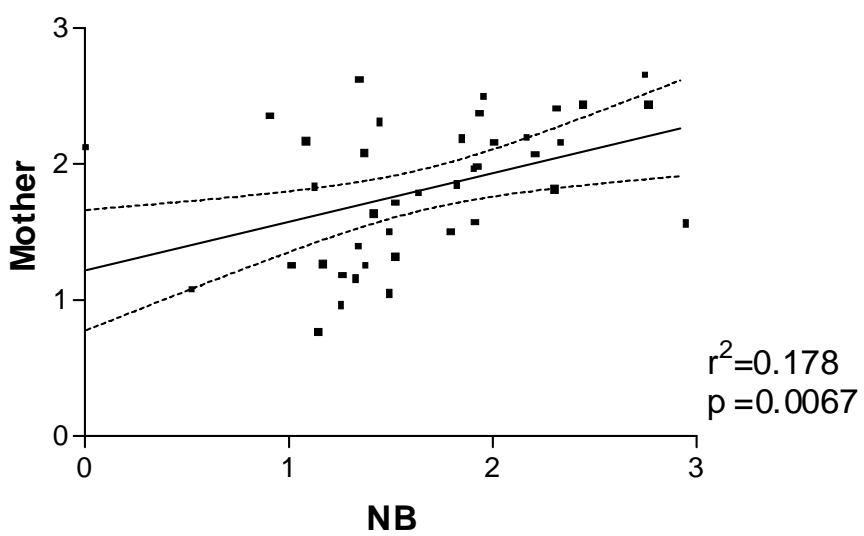

Fig. 2 - Correlation coefficient $\left(\mathrm{r}^{2}\right)$ between IgG levels of the mother and respective newborn (NB) using ELISA with T. cruzi antigens: (A) TESA- trypomastigotes excreted/secreted antigens; (B) EAE epimastigote alkalin extract. proved to be useful in these situations, since two of 54 newborns were positive by these methods.

The serological and parasitological tests concomitantly applied to newborns can be of help for the diagnosis of congenital Chagas' disease $12,15,26,27,32$. In some cases IgG or IgM antibody detection is not possible, as observed in case 2 (Table 1). Some hypotheses can be formulated to explain this fact. According to GRILL et al. ${ }^{15}$, fetal infection can occur at any gestational age and the fetus at birth can be in the chronic phase. More recently, LORCA et al. ${ }^{19}$ found IgM antibodies at birth in 8/12 newborns with congenital Chagas' disease and only after 1 to 2 months of life was possible to detect IgM antibodies in all children. The same authors explained this fact by the hypothesis of fetal infection in a late phase of the gestation, delaying the detection of IgM antibodies at birth. These hypotheses cannot explain the aspects found in case 2, which showed none of the Ig classes in spite of a marked parasitism. Some authors showed that IgG and IgM anti-T. cruzi antibodies could be adsorbed on the circulating bloodstream forms ${ }^{14}$.

In two of the present cases, the parasitological assays proved to be

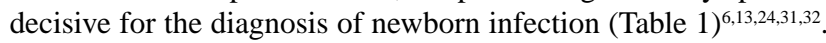

Our study showed by ELISA differences in the correlation between maternal IgG and newborn antibody titers at birth, depending on the $T$. cruzi antigens used (Fig. 2).

The frequent reports showing $T$. cruzi forms in the placenta and umbilical cord in cases of congenital Chagas' disease ${ }^{2,7}$ has led to the proposal of a correlation between congenital infection and presence of T. cruzi in these materials. Our data showed amastigote forms and $T$. cruzi fractions in the placenta and umbilical cord in case 3 (Table 1), supporting this hypothesis, since histological analysis of material from this stillborn was not possible.

IH is the method of choice for the detection of T. cruzi in tissues, since the amastigote forms can be confused with Toxoplasma gondii and Histoplasma capsulatum ${ }^{7}$. As observed in the present study, $\mathrm{IH}$ is very useful when the inflammatory response is not seen in the placenta as observed in case 1 and when the fetus is macerated ${ }^{7,16,17}$.

Congenital T. cruzi transmission at fetal level was confirmed in three cases, and in one case transmission was documented only at placental level.

The level of circulating T. cruzi parasites has been already mentioned as a possible factor for congenital Chagas' disease transmission ${ }^{8}$. The presence of anti-T. cruzi IgM antibodies during pregnancy as observed in two HIV positive mothers indicates of Chagas' disease reactivation. In urban centers ${ }^{9}$, heterosexual contamination with HIV virus is frequent, and the chances of pregnant women having both infections is high. In these cases the number of circulating $T$. cruzi could be increased ${ }^{29}$.

These results suggest the necessity of follow up of chagasic pregnant women coinfected with HIV, that presents high risk of T.cruzi transmission, and perinatal morbidity as previously reported ${ }^{12,13}$.

In spite of the presence of p24 HIV antigen in two placentas (cases 1 and 2), congenital HIV transmission was not investigated in our study, 


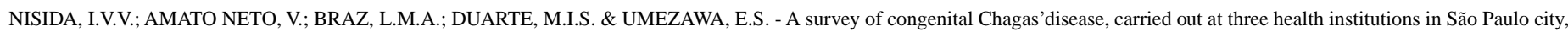
Brazil. Rev. Inst. Med. trop. S. Paulo, 41 (5): 305-311, 1999.

but previous data have shown that presence of HIV antigens in the placenta do not necessarily indicates fetal infection ${ }^{10,20,21,30}$.

The use of several parasitological, histopathological and immunohistochemical methods for the diagnosis of congenital Chagas' disease increases the possibility of diagnosis, since specific IgM antibodies are not always present in the infected newborn at birth.

\section{RESUMO}

\section{Doença de Chagas congênita em três instituições de saúde da cidade de São Paulo, Brasil}

A transmissão congênita da doença de Chagas continua a ser um problema no Brasil. Em um estudo com 58 recém-nascidos, de 57 mães com a forma crônica da doença de Chagas, selecionadas em três Instituições de Saúde da Cidade de São Paulo, a transmissão congênita foi demonstrada em $5,17 \%$ (3/58) dos casos, com um provável caso confirmado somente pelo achado de antígenos do T. cruzi na placenta e cordão umbilical. Os testes parasitológicos (microhematócrito, quantitative buffy coat-QBC ou xenodiagnóstico artificial) foram capazes de diagnosticar dois casos congênitos de infecção pelo T. cruzi, nascidos de mulheres chagásicas com infecção pelo HIV. A imunohistoquímica efetuada nestas duas placentas foi capaz de identificar formas amastigotas e antígenos do T. cruzi. A infecção congênita foi confirmada a nível placentário em outros dois casos, e a nível fetal em um destes casos por imunohistoquímica.

O Immunoblotting utilizando antígenos excretados/secretados de formas tripomastigotas do T. cruzi (TESA-blot), detectou anticorpos IgG em 54/55 dos casos e IgM em 1/55. Nos dois casos congênitos um apresentou anticorpos IgG e IgM o no outro não foram detectados anticorpos IgG ou IgM anti T. cruzi, apesar do achado de parasitas circulantes.

\section{ACKNOWLEDGEMENTS}

This work was supported by grants from FAPESP, CNPq and LIM49-FMUSP. We wish to thank the following persons for their help: M. Zugaib, S. Kahhale and M.R.F.L. Bortolotto; C.R. Leone; M.H. Lopes, M.A. Shikanai-Yasuda and A.A.C. Segurado, HC-FMUSP; DrV. Tadini, C. Mariani, T. Oliveira and S. Daré from Hospital-Maternidade Leonor Mendes de Barros; J. Andrade, M.G.R. Champi and A. Franchi Jr, Setor de Cardiopatia e Gravidez, Instituto Dante Pazzanese de Cardiologia; H. Franco Jr; A.O.D. Fernandez, C.R.M. Casadei, F.L. Carignani; N. Kesper Jr, and M.S. Santos from Instituto de Medicina Tropical FMUSP.

\section{REFERENCES}

1. AMATO NETO, V.; MATSUBARA, L. \& LANURA, P.N.B. - Avaliação do sistema quantitative buffy coat (QBC) no diagnóstico laboratorial da infecção pelo Trypanosoma cruzi: estudo em modelo experimental murino. Rev. Soc. bras. Med. trop., 29: 59-61, 1996.

2. AZOGUE, E. \& DARRAS, C. - Estudio prospectivo de la enfermedad de Chagas en recien nacidos con infección placentaria por Trypanosoma cruzi (Santa Cruz-Bolívia). Rev. Soc. bras. Med. trop., 24: 105-109, 1991.

3. AZOGUE, E. \& DARRAS, C. - Chagas congénito en Bolivia: estudio comparativo de la eficacia y el costo de los metodos. Rev. Soc. bras. Med. trop., 28: 39-43,1995.
4. BITTENCOURT, A.L.; SADIGURSKY, M. \& BARBOSA, H.S. - Doença de Chagas congênita. Estudo de 29 casos. Rev. Inst. Med. trop. S. Paulo, 17: 146-159, 1975.

5. BITTENCOURT, A.L. - Congenital Chagas' disease. Amer. J. Dis. Child., 130: 97-103, 1976

6. BITTENCOURT, A.L. - Incidence of congenital Chagas' disease in Bahia, Brazil. J. trop. Pediat., 31: 242-248, 1985.

7. BITTENCOURT, A.L.; MEDINA-LOPES, M.D. \& CAMARGO, M.E. - Doença de Chagas. In: DINIZ, E.M.A. \& VAZ, F.A.C. Infecções congênitas e perinatais. São Paulo, Atheneu, 1991. p.73-89.

8. BITTENCOURT, A.L. - Possible risk factors for vertical transmission of Chagas' disease. Rev. Inst. Med. trop. S. Paulo, 34: 405-408, 1992.

9. BRASIL. MINISTÉRIO DA SÁUDE. - Bol. epidem. AIDS, 10(3): 22-46, 1997.

10. CHANDWANI, S.; GRECO, M.A.; MITTAL, K. et al. - Pathology and human immunodeficiency virus expression in placentas of seropositive women. J. infect. Dis., 163: 1134-1138, 1990

11. DUARTE, M.I.S \& PAGLIARI, C. - Moléstias infecciosas. In: ALVES, V.A.F.; BACCHI, C.E. \& VASSALLO, J., ed. Manual de Imuno-histoquímica. São Paulo, Sociedade Brasileira de Patologia, 1999. p. 195-207.

12. FREILIJ, H. \& ALTCHEH, J. - Congenital Chagas' disease: diagnostic and clinical aspects. Clin. infect. Dis., 21: 551-555, 1995.

13. FREILIJ, H.; ALTCHEH, J. \& MUCHINIK, G. - Perinatal human immunodeficiency virus infection and congenital Chagas' disease. Pediat. infect. Dis. J., 14: 161-162, 1995

14. GASPARI, E.N.; STOLF, A.M.S.; UMEZAWA, E.S.; ZINGALES, B. \& ABRAHAMSOHN, I.A. - Trypanosoma cruzi: studies on the reactivity of antibodies bound to the surface of blood forms at the early phase of infection. Acta trop. (Basel), 56: $79-87,1994$

15. GRILL, D.; ELIZARI, M.; SZARFMAN, A.; URMAN, J. \& SCHMUÑIS, G.A. Anticuerpos anti-Trypanosoma cruzi en recién nacidos normales hijos de madres infectadas. Medicina (B. Aires), 36: 158-160, 1976.

16. LANA, A.M.A.; LAGES-SILVA, E. \& BARBOSA, A.J.A. - Doença de Chagas congênita: avaliação imunocitoquímica do parasitismo em tecidos de feto macerado. Rev. Soc. bras. Med. trop., 19: 95-98, 1986.

17. LANDMAN, G.; ALVES, A.C.; MENDES, N.F. \& MENDES, E. - Identification of Trypanosoma cruzi in human tissues using an immunoperoxidase method: study of acute Chagas' disease, congenital form. Allergol. Immunopath., 14: 509-513, 1986.

18. LISBOA, A.C. - Sobre a forma congênita da doença de Chagas. Rev. Inst. Med. trop. S. Paulo, 2: 319-324, 1960.

19. LORCA, M.; VELOSO, C.; MUNOZ, P.; BAHAMONDE, M.I. \& GARCIA, A. Diagnostic value of detecting specific IgA and IgM with recombinant Trypanosoma cruzi antigens in congenital Chagas' disease. Amer. J. trop. Med. Hyg., 52: $512-$ $515,1995$.

20. MATTERN, C.F.T.; MURRAY, K.; JENSEN, A. et al. - Localization of human immunodeficiency virus core antigen in term human placentas. Pediatrics, 89: 207 209, 1992.

21. MAURY, W.; POTTS, B.J. \& RABSON, A.B. - HIV-1 infection of first-trimester and term human placental tissue: a possible mode of maternal-fetal transmisssion. J. infect. Dis., 160: 583-588, 1989.

22. MEDINA-LOPES, M.D. - Transmissão materno-infantil da doença de Chagas Brasília, 1983. (Dissertação de Mestrado - Faculdade de Medicina da Universidade Federal de Brasília). 

Brazil. Rev. Inst. Med. trop. S. Paulo, 41 (5): 305-311, 1999.

23. MOTA, C.C.C. - Doença de Chagas congênita: estudo longitudinal das repercussões da infecção materna no concepto, do nascimento aos cinco anos de idade. Belo Horizonte, 1992. (Tese de Doutoramento - Faculdade de Medicina da Universidade Federal de Minas Gerais).

24. MOYA, P.; MORETTI, E.; PAOLASSO, R. et al. - Enfermedad de Chagas neonatal Diagnóstico de laboratório en el primeiro año de vida. Medicina (B. Aires), 49: 595-599, 1989

25. PESSÔA, S.B. \& MARTINS, A.V. - Doença de Chagas: diagnóstico, epidemiologia, profilaxia e terapêutica. In: PESSÔA, S.B. \& MARTINS, A.V. Parasitologia Médica Rio de Janeiro, Guanabara Koogan, 1988. p.144-185.

26. REYES, M.B.; LORCA, M.; MUNÕZ, P. et al. - Estudio materno-infantil de enfermedad de Chagas en zonas endemicas. IV Santiago. Region Metropolitana Chile. Bol. Hosp. S. Juan (Santiago), 35: 9-11, 1988

27. REYES, M.B.; LORCA, M.; MUÑOZ, P. \& FRASCH, A.C.C. - Fetal IgG specificities against Trypanosoma cruzi antigens in infected newborns. Proc. nat. Acad. Sci. (Wash.), 87: 2846-2850, 1990.

28. SANTOS, R.T.M.; WAKAMATSU, A.; KANAMURA, C.T.; NONOGAKI, S. \& PINTO, G.A. - Procedimentos laboratoriais em imuno-histoquímica e hibridização "in situ". In: ALVES, V.A.F.; BACCHI, C.E. \& VASSALLO, J., ed. Manual de Imunohistoquímica. São Paulo, Sociedade Brasileira de Patologia, 1999. p. 237-259.
29. SARTORI, A.M.C ; SHIKANAI-YASUDA, M.A ; AMATO NETO, V \& LOPES, M. H - Follow-up of 18 patients with human immunodeficiency virus (HIV) infection and chronic Chagas' disease with reactivation of Chagas' disease causing cardiac disease in three patients. Clin. infect. Dis., 26: 177-179, 1998.

30. SOEIRO, R.; RUBINSTEIN, A.; RASHBAUM, W.K. \& LYMAN, W.D. - Maternofetal transmission of AIDS: frequency of human immunodeficiency virus type I nucleic acid sequences in human fetal DNA. J. infect. Dis., 166: 699-703, 1992.

31. STREIGER, M.; FABBRO, D.; DEL BARCO, M.; BELTRAMINO, R. \& BOVER, N. Congenital Chagas' disease in the city of Santa Fe. Diagnosis and treatment. Medicina (B. Aires), 55: 125-132, 1995.

32. UMEZAWA, E.S.; NASCIMENTO, M.S., KESPER JR., N. et al. - Immunoblot assay using excreted-secreted antigens of Trypanosoma cruzi in serodiagnosis of congenital, acute, and chronic Chagas' disease. J. clin. Microbiol., 34: 2143-2147, 1996.

33. UMEZAWA, E.S.; SHIKANAI-YASUDA, M.A.; GRUBER, A.; PEREIRA-CHICCOLA, V.L. \& ZINGALES, B. - Trypanosoma cruzi defined antigens in the serological evaluation in an outbreak of acute Chagas' disease in Brazil (Catolé do Rocha, Paraíba). Mem. Inst. Oswaldo Cruz, 91: 87-93, 1996.

Received: 12 May 1998

Accepted: 18 October 1999 